\title{
Topical estradiol does not interfere with the expression of the metalloproteinase-1 enzyme in photo exposed skin cells
}

\author{
Estradiol tópico não interfere na expressão da enzima metaloproteinase-1 \\ em células da pele fotoexposta
}

\author{
Luciana Neder ${ }^{1}$
}

\author{
Sebastião Freitas de Medeiros ${ }^{2}$
}

\begin{abstract}
BACKGROUND: In postmenopausal women there is a rapid destruction of dermal collagen, resulting in accelerated skin ageing, which is manifested by cutaneous atrophy, increased number and depth of wrinkles and sagging. This accelerated catabolism of the collagen is due to estrogen deficiency and increased synthesis of the metalloproteinase-1 enzyme, which degrades the dermal collagen.

Овјестіves: To assess whether the use of topical estradiol $0.05 \%$ cream on photo exposed skin can inhibit the expression of the metalloproteinase- 1 enzyme on the dermis and subsequently the rapid loss of collagen in women after menopause.

METHODS: We included 40 postmenopausal women without hormone replacement therapy. Information about lifestyle, lipid profile, blood glucose level, thyroid hormones, mammography, Pap smear and transvaginal ultrasound were obtained to rule out associated diseases. Skin biopsy of the right preauricular region was performed before and after treatment with topical estradiol $0.05 \%$ for 30 days. The biopsy specimens were subjected to immunohistochemistry to identify the expression of the metalloproteinase-1 enzyme.

RESULTS: There was no statistically significant difference on the expression of the metalloproteinase-1 enzyme in keratinocytes, fibroblasts and endothelial cells before and after treatment with topical estradiol for 30 days.

ConCLUSION: Treatment with estradiol $0.05 \%$ cream, in photo exposed skin for 30 days, does not inhibit the production of metalloproteinase-1.

Keywords: Estradiol; Menopause; Metalloproteinases; Skin aging

Resumo: FunDAMENTOS: Na pós-menopausa, ocorre rápida destruição do colágeno dérmico, com consequente envelhecimento acelerado da pele, que se expressa com atrofia cutânea, aumento do número e da profundidade das rugas e flacidez. Esse catabolismo acelerado do colágeno ocorre por deficiência estrogênica e aumento na síntese da enzima metaloproteinase-1, que degrada o colágeno dérmico.

OвjEтtvos: Avaliar se o uso de estradiol tópico a $0,05 \%$ em creme na pele fotoexposta pode inibir a expressão da enzima metaloproteinase- 1 na derme e, consequentemente, a perda acelerada do colágeno em mulheres na pósmenopausa.

MÉTODOS: Foram incluídas 40 mulheres na pós-menopausa sem terapia de reposição hormonal. Informações sobre hábitos de vida, perfil lipídico, níveis glicêmicos, hormônios tireoidianos, mamografia, colpocitologia oncótica e ultrassom transvaginal foram obtidas para excluir doenças associadas. Biópsia de pele da região pré-auricular direita foi realizada antes e após tratamento com estradiol tópico a 0,05\% por 30 dias. Os espécimes de biópsia foram submetidos à reação imunoistoquímica para identificar a expressão da enzima metaloproteinase-1.

RESUlTADOS: Não foi observada diferença estatisticamente significativa na expressão da enzima metaloproteinase-1 em queratinócitos, células endoteliais e fibroblastos da pele antes e após tratamento com estradiol tópico por 30 dias.

CONCLUSÃO: O tratamento com creme contendo estradiol a $0,05 \%$ em pele fotoexposta por 30 dias não inibe a produção da enzima metaloproteinase-1.

Palavras-chave: Envelhecimento da pele; Estradiol; Menopausa; Metaloproteinases
\end{abstract}

Received on 21.11.2010.

Approved by the Advisory Board and accepted for publication on 03.12.10.

* Work performed at the Hospital Universitário Julio Muller - (HUJM) Universidade Federal de Mato Grosso (UFMT) - Cuiabá (MT), Brasil.

Conflict of interest: None / Conflito de interesse: Nenbum

Financial funding: None / Suporte financeiro: Nenhum

Assistant Professor in Dermatology and Internal Medicine of the Universidade Federal de Mato Grosso - UFMT - Cuiabá (MT), Brasil

PhD - Assistant Professor of Gynecology and Obstetrics of the Universidade Federal de Mato Grosso (UFMT) - Cuiabá (MT), Brasil.

C 2012 by Anais Brasileiros de Dermatologia 


\section{INTRODUCTION}

The life expectancy of the Brazilian woman, which five decades ago was approximately 50 years, is currently over 70 years, and women are now living many years on the postmenopausal period. ${ }^{1,2}$ With the increasing number of this population, many researches are being developed with the aim of studying the risks and benefits of oestrogen replacement therapy in various systems in postmenopausal women. ${ }^{3,4}$ The hormonal replacement therapy (HT) with oestrogens (OT), or oestrogens with progesterone (OPT) on the menopause improves hot flashes, mood swings, genital epithelium atrophy, loss of libido, and sleep disturbances ${ }^{5}$. Equally important is its beneficial effect in decreasing the risk of osteoporosis, fractures and skin ageing.

Skin ageing is caused by a combination of facts, including genetic predisposition, hormonal causes, exposure to ultraviolet light and lifestyle (nutrition, nicotine, alcohol, drugs) and catabolic factors like infections and tumors. ${ }^{6}$ While the effects of oestrogens in various organs are well established, the influence of these hormones on the skin is still scarcely known. It is known the on the postmenopausal climacteric there is an acceleration of cutaneous ageing. During this period the women report decrease of skin hydration, loss of firmness, decrease of elasticity and increase of sagging. ${ }^{7-10}$ There is a correlation between these clinical signs and symptoms and histological phenomenon on the skin, highlighting the epidermic atrophy, decrease of collagen and elastin, alteration of the proportion between collagen types I and II and changes on the vasculature. ${ }^{11-12}$

The decrease of skin collagen in adults is around 1\% each year, becoming more evident in women than in men. In women around $30 \%$ of the total collagen of the skin is lost during the first five years of post menopause. ${ }^{6,13}$ After this accelerated loss there is an average annual decline of $2,1 \%$, for a period of 20 years $^{14}$. This way, the ageing skin is thinner due to the decrease of epidermal keratinocytes and the loss of connective tissue and the fundamental substance of the dermis, rich in glucosaminoglicans. These degenerative changes that go along with the ageing process result in atrophy, sagginess and skin wrinkling. ${ }^{8}$

The oestrogens, via receptors, regulate various cell functions, including proliferation, morphogenesis, differentiation and apoptosis. ${ }^{14}$ The oestrogenic receptors are present in all the cells of our body, including the epidermal keratinocytes, dermal fibroblasts, sebaceous glands, hair follicles, and skin glands and vessels. ${ }^{14}$ The strong expression of these receptors on the dermal fibroblasts suggests the direct participation of the oestrogens in stimulating the col- lagen synthesis via the transforming growth factor $(\text { TGF } \beta)^{15}$. Estradiol stimulates the proliferation and the synthesis of keratinocytes DNA, resulting in thickening of the epidermis and higher skin hydration by decreasing the trans-epidermic water loss. This steroid still increases both the epidermic lipids layer and the content of glucosaminoglicans, especially of hyaluronic acid. ${ }^{6,13,16}$ The oestrogen deprivation is also associated with degenerative abnormalities of the dermal elastic fibers, and there are reports of increased synthesis of theses fibers after use of a cream containing estriol. ${ }^{11,17-18}$ Most studies already done with oestrogens replacement, both oral and topical, show increment of cutaneous thickness and dermic collagen. ${ }^{19}$

The collagen is degraded by the matricial metalloproteinase enzymes (MMP) on the most diverse organs, including skin fibroblasts. The various types of metalloproteinase cleave the dermal collagen as well as the glucosaminoglicans, elastin and other constituents of the dermal matrix. The mechanism that regulates the increment of the collagen synthesis on the skin by the estradiol includes, besides the TGF $\beta$, the multifunctional cytokines, with important role on the growth regulation, cell differentiation and biosynthesis of extracellular connective tissue. ${ }^{14,20}$ This cytokine stimulates the fibroblast proliferation on the dermis and induces the synthesis and secretion of most proteins of the extracellular matrix (collagens I, III, VII, elastine and hyaluronic acid). In addition, TGF $\beta$ inhibits the expression of the metalloproteinase enzymes, including the MMP-1, responsible for the degradation of the dermal matrix proteins, like the collagen. ${ }^{2,3,7}$

The use of topical $17 \beta$ estradiol applied to the body skin of elderly people enhances the expression of type I pro-collagen, mostly in women. ${ }^{20}$ It was also confirmed that the use of topical $17 \beta$ estradiol can stimulate the collagen synthesis and decrease the in vivo synthesis of MMP-1, preserving the skin structure. However, the use of oestrogens on the post menopause is still a controversial issue because, despite controlling the menopause symptoms, decreasing the risk of vertebral fractures, decreasing the risk of colorectal cancer, improving the cognitive functions, decreasing the risk of dementia and improving the quality of life, it can have well defined risks like the increase of breast cancer and thromboembolism ${ }^{14,21}$. It is still not known whether the use of topical oestrogens on the face would have the same beneficial effects of attenuating cutaneous ageing, without causing any harm to the patient. Besides this, more studies are still necessary to establish the minimal dose necessary to obtain the best results without systemic adverse effects. ${ }^{22}$ The 
present study has the objective of assessing if topical estradiol, on the concentration of $0,05 \%$, applied to the skin, can inhibit the synthesis of the MMP-1 enzyme in skin cells.

\section{METHOD}

This prospective, interventional study was approved by the Research Ethics Committee of the Hospital Universitário Julio Muller da Universidade Federal de Mato Grosso. Considering an alpha error of $5 \%$, power of $80 \%$, average of increment on procollagen type I expression of $3,5 \%$ and standard deviation of $2,3 \%$, loss of $40 \%$, the minimum sample size, estimated by the formula $\mathrm{n}=2+\mathrm{c}(\mathrm{s} / \mathrm{d}) 2$, [where $\mathrm{p}=$ standard deviation, $\mathrm{d}=$ estimated difference between the averages and $c=$ constant dependent on the level of significance $(\alpha)$, the study power $(1-\beta)]$ was 13 patients. In total, 40 volunteers seen at the Climacteric outpatients' clinic of the Hospital Universitário Julio Muller of the Universidade Federal de Mato Grosso were assessed. ${ }^{2,23,24}$ Eligibility criteria considered women with postmenopausal hypooestrogenism, aged between 40 and 65 years and with moderate/severe signs of cutaneous ageing, as long as they were able to read, accept and sign the Free and Explained Consent Form. Women with history of breast cancer, endometrial cancer, cutaneous allergies or skin diseases which contraindicated the use of topical oestrogen were excluded. The research would be suspended if there was intolerance to the use of topical estradiol.

During the initial interview the finality of the study and the methods used were explained to the patients. After their consent a complete medical history was obtained and routine laboratory tests were performed at the Climacteric outpatients clinic: hemogram, fasting glucose level, lipidic profile, FSH, LH, estradiol, TSH, free T4, faecal occult blood test, Pap smear, mammography, transvaginal ultrasound and bone densitometry. At the end of the interview the patient went through a detailed physical examination. After confirmation of the eligibility, the first skin biopsy was done. The biopsy was done in the morning on the right preauricular area and the patient was advised to take the dressing early in the evening. After the biopsy the patient received the medication and was advised to apply daily, all over the face, for 30 days, the estradiol gel in a sachet containing $0,5 \mathrm{mg}$ of estradiol in $0,5 \mathrm{~g}$ gel (Sandrena gel $^{\circledast}, 0,5 \mathrm{mg} / 0,5 \mathrm{~g}$, Organon ${ }^{\circledast}$, Brasil). After this advice a return visit was scheduled for 30 days for another biopsy and finalizing of the study. The control biopsy was done $1 \mathrm{~cm}$ below the first one. After collection, the material was processed on the Pathology Laboratory of the Hospital Universitário Julio Muller of the Universidade Federal de Mato Grosso and dyed for the immunohistochemistry for MMP-1. In this process the primary antibody anti MMP-1 (Polyclonal antibody to MMP-1, DBS Diagnostic Biosystems ${ }^{\circledR}$, Advanced Medical Science Co. Ltd, Chatujak Bangkok, Tailand), diluted at 1:50 and the detection antibody (Mach 4 Mouse) provided by ProbeBiocare Medical ${ }^{\circledast}$, Biocare Material Médico
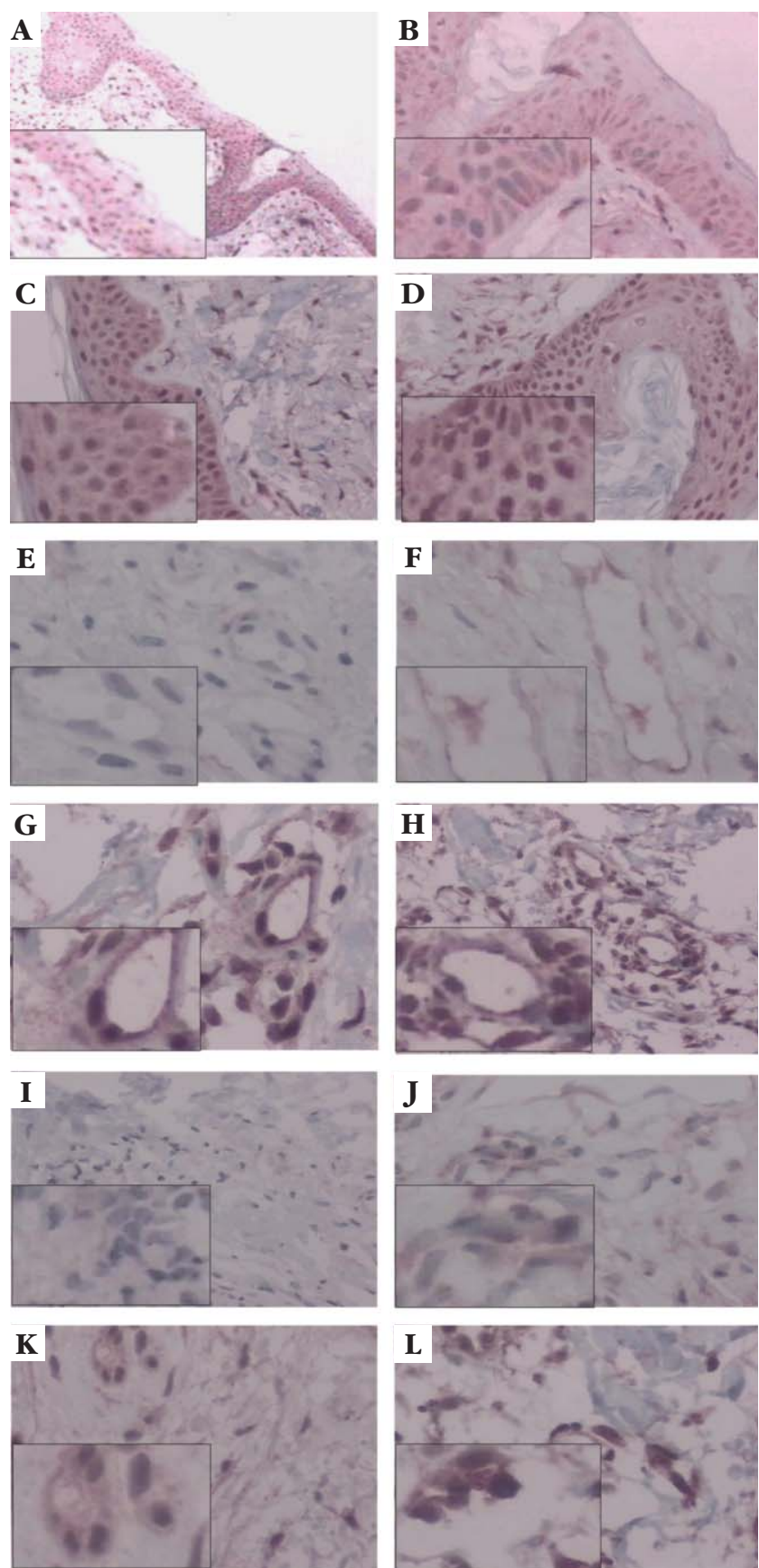

FIGURE 1: Microphotography of skin specimens showing expression of the metalloproteinase-1 enzyme on the epidermis, endothelial cells and fibroblasts: $\mathrm{a}, \mathrm{e}, \mathrm{i}=$ absence of expression $(0+)$; $\mathrm{b}, \mathrm{f}, \mathrm{j}=$ weak expression $(1+) ; \mathrm{c}, \mathrm{g}, \mathrm{k}=$ moderate expression $(2+)$; d,h,l = strong expression $(3+)$ 
Hospitalar Ltda, Rio de Janeiro, RJ were used. Using the semi-quantitative method the expression of MMP1 in increasing order of intensity was quantified, as follows: $0=$ absence of expression; $1+=$ weak expression; $2+=$ moderate expression; and $3+=$ strong expression (Figure 1) ${ }^{25}$. In case of different levels of expression on the same slide the area with the strongest expression was considered. The MMP-1 expression was analysed separately by two independent observers on both the pre- oestrogenic therapy sample and on the sample obtained after the treatment. In case of discordance between the examiners the slides were simultaneously re-examined in a meeting with both of them, and consensus was reached.

The distribution of the variables was verified by the Lilliefors test and the results shown according to its distribution. Variables with normal distribution are presented as average and standard deviation. The

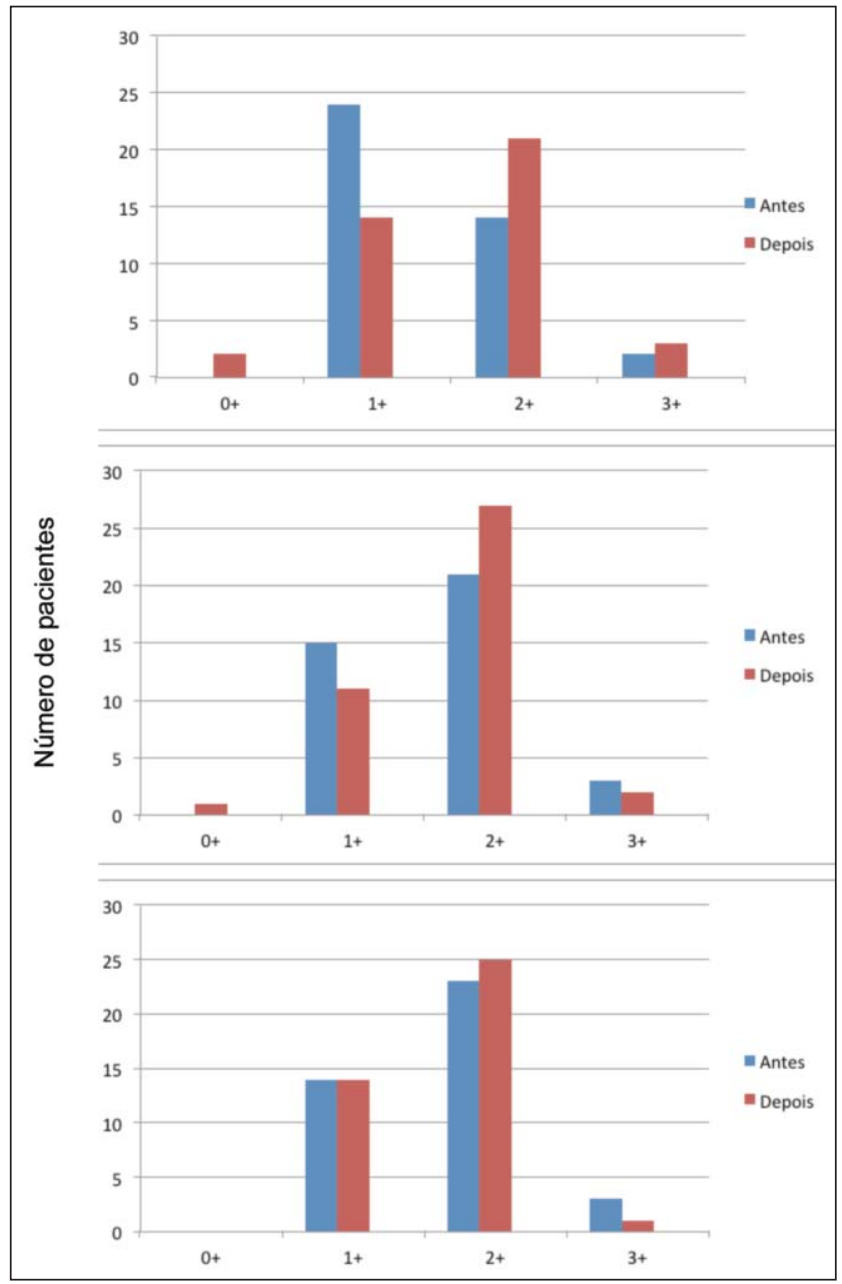

FIGURE 2: Distribution of the patients by intensity of the expression of the metalloproteinase-1 enzyme in keratinocytes (A), endothelial cells (B) and fibroblasts (C), before and after the use of topical estradiol $0,05 \%$ variables with non-parametric distribution are described and median and amplitude. The results are shown in charts. The immunohistochemical scores of the different cell types were analysed using the nonparametric Wilcoxon signed rank test, for paired samples. The results were considered statistically significant when $\mathrm{p}<0,05$. The data was analysed using the STATA 10 program.

\section{RESULTS}

In terms of age, the patients were between 43 and 65 years, average of 53,3 $\pm 5,3$ years. They had been on menopause from between 1 and 22 years, median of 7 years. Only two patients (5\%) had occupations that required higher sun exposure. Thirteen $(32,5 \%)$ were smokers or ex-smokers and eight were white (20\%), 10 were black (25\%) and twenty-two from other races $(55 \%)$.

When considering the expression of metalloproteinase- 1 on the different subtypes of the cutaneous cells studied (keratinocytes, fibroblasts and endothelial cells), it was observed that in none of them there was a significative expression of this enzyme after the treatment with topical estradiol for 30 days. In a joint analysis, it was demonstrated that the use of a cream containing estradiol $0,05 \%$, for 30 days, did not inhibit the expression of the MMP-1 enzyme on the skin keratinocytes $(p=0,067)$, fibroblasts $(p=0,15)$, or endothelial cells $(\mathrm{p}=0,83)$ (Figure 2).

\section{DISCUSSION}

In women, the decline of the oestrogenic levels is associated with a variety of cutaneous alterations, many of them reversible or improved by oestrogen replacement therapy. Amongst the most common alterations the thinning of the skin, decrease of the content of collagen and elastin, increase of wrinkles, dryness and difficulty in healing are seen. ${ }^{7.9}$ Previous studies about the effects of oestrogen replacement on the skin used different diagnostic methods and measures of the response and different doses, types and administration vias of oestrogen. Previous clinical studies showed that the thickness of the skin is increased in women that receive hormonal replacement therapy. Some of these studies also used progestogens or androgens in combination with oestrogens, coming to different results.

With the utilization of various analysis methods (ultrasound with photos analysed by computer programs and computerized profilometry) and different study designs (clinical double blind, placebo controlled), an improvement of the wrinkles and skin hydration has been observed. There are also studies assessing the dosage of cutaneous lipids before and after replacement therapy. Studies using ultrasound 
showed increment of the epidermal and dermal thickness, the results concordant with biopsy analysis that also showed increased epidermal and dermal thickness. ${ }^{9,26}$ The skin thickness has a close relationship with the collagen content and many studies have shown the increase of this substance through biopsy with optic and electronic microscopy analysis and immunohistochemistry. It has also been observed, through immunohistochemical analysis, an increased concentration and size of elastic fibers. Many studies did not take into consideration confounding factors like solar exposure and smoking, known important facts in influencing the cutaneous ageing process, resulting in conflicting findings and conclusions on the literature.

On the present study the expression of the MMP-1 enzyme on skin keratinocytes, endothelial cells and fibroblasts after 30 days of topical oestrogen therapy was analysed. These results differ from previous observation. ${ }^{14}$ However, the study against which the present studies were compared used 17ßestradiol in a photo protected area and Western blot to ascertain the activity of this enzyme. ${ }^{14}$ In fact, some studies have demonstrated beneficial effects of systemic and topical treatment with oestrogens in photo protected areas. The fact that the present study was done on the face, subjected to chronic sun exposure, might have contributed to the absence of response after oestrogenic therapy. This observation is suppor- ted by other studies that, when comparing collagen synthesis in photo exposed and photo protected areas, showed lower collagen synthesis in photo exposed areas, despite the similar expression of the oestrogenic receptors in both areas.

The time spent under hypooestrogenic environment might also have contributed to the lower expression of MMP-1 after treatment. On the present study, the time of post menopause varied from 1 to 22 years, with a median of 7 years. It is known that women with less than 2 years of oestrogen deprivation have higher gain in skin thickness with oestrogenic therapy when compared to women in more advanced periods of menopause. ${ }^{27}$ It is possible that a longer treatment, with higher doses of oestrogen, a higher number of participants and use in photo protected areas might bring more benefits. Future investigations should also systematically stratify the participants by time of oestrogenic deprivation, lifetime sun exposure, smoking and basal level of estradiol at the beginning of the treatment.

\section{CONCLUSION}

The immunohistochemical expression of the MMP-1 enzyme was not modified after treatment of the photo exposed skin with topical estradiol $0,05 \%$ for 30 days. In this sense, additional studies are necessary to better understand the role of MMP-1 on the cutaneous ageing process in postmenopausal women. 


\section{REFERENCES}

1. Instituto Brasileiro de Geografia e Estatística (IBGE). Diretoria de Pesquisas (DPE), Coordenação de População e Indicadores Sociais, Projeção da população do Brasil por sexo e idade para o período 1980-2050. tabela1, pg 4. Revisão 2008. [acesso 16 Março 2008]. Disponível em: www.ibge.gov.br/home/estatistica/ populacao/tabuadevida/2007

2. Kligman AM, Koblenzer C. Demographics and psychological implications for the aging population. Dermatol Clin. 1997;15:549-53.

3. Shan MG, Maibach HI. Estrogen and skin an overview. Am J Clin Dermatol. 2001;2:143-50

4. Albright F, Smith PH, Richardson AM. Postmenopausal osteoporosis its clinical features. JAMA. 1941;116:2465-74.

5. Palacios S. Current perspectives on the benefits of HRT in menopausal women. Maturitas. 1999;33:S1-S13.

6. Sator PG, Schimidt JB, Rabe T, Zouboulis ChC. Skin aging and sex hormones in women clinical perspectives for intervention by hormone replacement therapy. Exp Dermatol. 2004;13(Suppl 4): 36-40.

7. Callens A, Vaillant L, Lecomte P, Berson M, Gall Y, Lorette G. Does hormonal skin aging exist? A study of the influence of different hormone therapy regimens on the skin of postmenopausal women using non-invasive measurement techniques.Dermatology.1996;193:289-94.

8. Affinito P, Palomba S, Sorrentino C, Di Carlo C, Bifulco G, Arienzo MP. Effects of postmenopausal hypoestrogenism on skin collagen. Maturitas. 1999;33:239-47.

9. Brincat M, Moniz CJ, Studd JW, Darby A, Magos A, Emburey G. Long-term effects of the menopause and sex hormones on skin thickness. $\mathrm{Br} J$ Obstet Gynecol.1985;92:256-9.

10. Brincat M, Versi E, Moniz CF, Magos A, de Trafford J, Studd JW. Skin collagen changes in postmenopausal women receiving different regimens of estrogen therapy. Obstet Gynecol. 1987;70:123-7.

11. Brincat MP. Hormone replacement therapy and the skin. Maturitas. 2000;35:107-17.

12. Broniarczyk-Dyla G, Joss-Wichman E. Ageing of the skin during menopause. J Eur Acad Dermatol Venereol. 2001;15:494-5.

13. Shuster S, Black M, McVitie E. The influence of age and sex on skin thickness, skin collagen and density. Br J Dermatol. 1975;93:639-43.

14. Son ED, Lee JY, Lee S, Kim MS, Lee BG, Chang IS, et al. Topical application of 17$\beta$ estradiol increases extracellular matrix protein synthesis by stimulating TGF $\beta$ signaling in aged human skin in vivo. J Invest Dermatol. 2005;124:1149-61.

15. Ashcroft GS, Dodsworth J, Van Boxtel E, Tarnuzzer RW, Horan MA, Schultz GS, et al. Estrogen accelerates cutaneous wound healing associated with a increase in TGF-beta1 levels. Nat Med. 1997;3:1209-15.

16. Grosman N. Studies on the hyaluronic acid protein complex the molecular size of hyaluronic acid and the exchangability of chloride in skin of mice before and after estrogen treatment. Acta Pharmacol Toxicol. 1973;33:201-8.
17. Pierard GE, Letawe C, Dowlati A, Pierard-Franchimont C. Effect of hormone replacement therapy for menopause on the mechanical properties of skin. J Am Geriatr Soc. 1995;43:662-5.

18. Dunn LB, Damesyn M, Moore AA, Reuben DB, Greendale GA. Does estrogen prevent skin aging? Results from the First National Health and Nutrition Examination Survey (NHANES I). Arch Dermatol. 1997;133:339-42.

19. Carr BR. Disorders of the ovaries and female reproductive tract. In Wilson JD, Foster DW, Kronenberg HM, Larsen PR, editors. Williams textbook of endocrinology. $9^{\text {th }}$ ed. Philadelphia: WB Saunders; 1998. p.751-817.

20. Massague J. The transforming growth factor-beta family. Annu Rev Cell Biol. 1990;6:597-641.

21. RiveraWoll LM, Davis SR. Postmenopausal hormone therapy: the pros and cons. Int J Med. 2004;34:109-14.

22. Schmidt JB, Binder M, Demschik G, Bieglmayer C, Reiner A. Treatment of skin aging with topical estrogens. Int J Dermatol. 1996;35:669-74.

23. Rittié L, Kang S, Voorhees JJ, Fisher GJ. Induction of collagen by estradiol. difference between sun-protected and photodamaged human skin in vivo. Arch Dermatol. 2008;144:1129-40.

24. Snedecor G, Cochran W, Cox D. Statistical methods. 8th ed. lowa: The lowa State University; Ames; 1989. p.503.

25. Bakos RM, Bakos L, Edelweiss MIA, Cartell A, Mariante JC, Masiero NCMS Immunohistochemical expression of matrix metalloproteinase-2 and -9 in melanocytic nevi is altered by ultraviolet B. Photodermatol Photoimmunol Photomed.2007;23:250-4

26. Punnonen R, Lovgren T, Kouvonen I. Demonstration of estrogen receptors in the skin. J Endocrinol Invest. 1980;3: 217-21.

27. Brincat M, Yuen AW, Studd JW, Montgomery J, Magos AL, Savvas M. Response of skin thickness and metacarpal index to estradiol therapy in postmenopausal women. Obstet Gynecol. 1987;70:538-41.

MAILING ADDRESS / ENDEREÇO PARA CORRESPONDEANCIA:
Sebastião Freitas de Medeiros
Rua Almirante Henrique Pinbeiro Guedes, 195
Duque de Caxias
78043-306 Cuiabá, MT, Brazil
Phone: (55 65) 3322-2017
Fax: (5565) 3623-0071
E-mail: de.medeiros@terra.com.br

How to cite this article/Como citar este artigo: Neder L, de Medeiros SF. Topical estradiol does not interfere with the expression of the metalloproteinase-1 enzyme in photo exposed skin cells. An Bras Dermatol. 2012;87(1):70-5. 